\title{
Molecular Regulation and Rejuvenation of Muscle Stem (Satellite) Cell Aging
}

\author{
Anna Meiliana ${ }^{1,2 *}$, Nurrani Mustika Dewi², Andi Wijaya ${ }^{2,3}$ \\ ${ }^{1}$ Postgraduate Program in Clinical Pharmacy, Padjadjaran University, Jl. Eijkman No.38, Bandung, Indonesia \\ ${ }^{2}$ Prodia Clinical Laboratory, Jl. Cisangkuy No.2, Bandung, Indonesia \\ ${ }^{3}$ Postgraduate Program in Clinical Biochemistry, Hasanuddin University, Jl. Perintis Kemerdekaan Km.10, Makassar, Indonesia \\ *Corresponding author. E-mail: anna.meiliana@prodia.co.id
}

Received date: Jun 3, 2015; Revised date: Jun 17, 2015; Accepted date: Jun 19, 2015

\section{Abstract}

B ACKGROUND: Age-related muscle loss leads to lack of muscle strength, resulting in reduced posture and mobility and an increased risk of falls, all of which contribute to a decrease in quality of life. Skeletal muscle regeneration is a complex process, which is not yet completely understood.

CONTENT: Skeletal muscle undergoes a progressive agerelated loss in mass and function. Preservation of muscle mass depends in part on satellite cells, the resident stem cells of skeletal muscle. Reduced satellite cell function may contribute to the age-associated decrease in muscle mass. Recent studies have delineated that the aging process in organ stem cells is largely caused by age-specific changes in the differentiated niches, and that regenerative outcomes often depend on the age of the niche, rather than on stem cell age. It is likely that epigenetic states will be better define such key satellite cell features as prolonged quiescence and lineage fidelity. It is also likely that DNA and histone modifications will underlie many of the changes in aged satellite cells that account for age-related declines in functionality and rejuvenation through exposure to the systemic environment.

SUMMARY: Skeletal muscle aging results in a gradual loss of skeletal muscle mass, skeletal muscle function and regenerative capacity, which can lead to sarcopenia and increased mortality. Although the mechanisms underlying sarcopenia remain unclear, the skeletal muscle stem cell, or satellite cell, is required for muscle regeneration. Decreased muscle stem cell function in aging has long been shown to depend on altered environmental cues, whereas the contribution of intrinsic mechanisms remained less clear. Signals in the aged niche were shown to cause permanent defects in the ability of satellite cells to return to quiescence, ultimately also impairing the maintenance of self-renewing satellite cells. Therefore, only anti-aging strategies taking both factors, the stem cell niche and the stem cells per se, into consideration may ultimately be successful.

KEYWORDS: satellite cell, muscle, aging, niche, regenerations

Indones Biomed J. 2015; 7(2): 73-86

\section{Introduction}

Skeletal muscle is the dominant organ system in locomotion and energy metabolism.(1) Skeletal muscle is the largest tissue in human body, composing $40-50 \%$ of total human body mass.(2) The functions of skeletal muscles include movement, breathing, and posture maintenance.(3) Skeletal muscles consist of muscle cells, networks of nerves and blood vessels, and connective tissues that connect individual fibers into bundles, which form the muscle.(4)

Myofibers are the basic structural elements of skeletal muscle and are composed of multiple fused myoblasts. (4) The skeletal muscle plays important roles in whole body energy metabolism, insulin sensitivity, and motility. Adult skeletal muscles have a remarkable capacity to regenerate after damage due to the contribution of a population of muscle resident stem cells called satellite 
cells.(5-8) Lineage tracing and transplantation studies have demonstrated that satellite cells can undergo efficient selfrenewal and myogenic differentiation in vivo, two defining features of stem cells.(8-10) In adult resting muscles, satellite cells are predominantly quiescent, heterogeneous, and reside between the basal lamina and plasma membrane of myofibers. $(11,12)$ Upon muscle injury, quiescent satellite cells are activated to proliferate, differentiate, and fuse into multinuclear myofibers, resulting in repair of the damaged muscle. $(13,14)$

Skeletal muscles are able to self-regenerate after injury. Crucial cells in this process are the satellite cells, which are located between the sarcolemma and the basal lamina of the myofiber. $(15,16)$ After injury these cells are activated, they proliferate and eventually fuse to the damaged myofibers or fuse together to form new myofibers. (17-20) Injury and diseases such as Duchenne muscular dystrophy (DMD) lead to impaired muscle function. The formation of a dysfunctional scar tissue during regeneration may account for this problem.(21)

It is well established that the human aging process is associated with a significant decline in neuromuscular function and performance.(22-24) Characteristic of this decline is the inevitable reduction in skeletal muscle mass and associated loss of strength, so-called sarcopenia, that occurs even in the absence of disease specifically affecting the neuromuscular system. Strength decline in upper and lower limb muscles is typically $20-40 \%$ by the $7^{\text {th }}$ decade and greater in older adults. This is accompanied by similar losses of limb muscle cross-sectional area.(25) Molecular understanding, combined with data that human satellite cells remain intrinsically young, introduced novel therapeutic targets.(26)

\section{Stem Cell Hypothesis of Aging}

Movement is a defining feature of all animals, even if it is sometimes restricted to specific developmental stages. (1) In all muscle cells, myosin II motor proteins and actin filaments generate force and movement. In the striated muscles that are used for locomotion, actomyosin contraction is amplified in serial and parallel arrangements of numerous contractile units, called sarcomeres. These are made up of actin and myosin filaments arranged in highly ordered, almost crystalline arrangements, as well as hundreds of regulatory proteins such as the troponintropomyosin complex, and scaffolding and cytoskeletal crosslinking proteins such as $\alpha$-actinin, myomesin and the kinase titin. $(27,28)$ In vertebrates, striated muscle cells are found in two tissues, skeletal and heart muscle. Although both have highly ordered myofibril structures, they have distinct embryonic origins and are tailored for particular purposes by different genetic programmes. Furthermore, in vertebrates specialized skeletal muscles with different contractile (slow-twitch or fast-twitch) and metabolic properties coexist. $(29,30)$

Skeletal muscle has evolved to allow precise movement in animals. By some estimates, there are around 640 skeletal muscles in human body, which together account for $\sim 38 \%$ of total body mass for men and $30 \%$ for women. (32) The functional units responsible for skeletal muscle contraction are cylindrical, multinucleated muscle fibers (myofibers). These contractile structures are established during embryogenesis, when mononuclear cells known as myoblasts fuse into immature myofibers (myotubes). The myofiber nuclei (myonuclei) are postmitotic and under normal conditions can not reenter a proliferative state to contribute additional nuclei. During postnatal life, myofiber growth, homeostasis, and repair rely on satellite cells, myogenic stem cells residing between the myofiber plasmalemma and basal lamina.(15,33-35)

A skeletal muscle is composed of many bundles of myofibers. A single myofiber is derived from the fusion of numerous myoblasts and therefore contains many nuclei. Each myofiber contains many myofibrils, which are composed of repeating sarcomeres. A sarcomere is an arrangement of the contractile proteins myosin and actin, which form the thick and thin filaments, respectively. These proteins are key elements for the contractile properties of skeletal muscle. For skeletal muscle to contract, the myofibers depolarize as a consequence of nerve activation. This results in the release of intracellular calcium from the sarcoplasmatic reticulum. Calcium causes binding of myosin to actin, and subsequently contraction of the myofibers and the entire skeletal muscle. Most human skeletal muscles contain a mixture of three different types of myofibers. Type 1 myofibers are slow twitch and fatigue resistant, type $2 \mathrm{~A}$ myofibers are fast twitch and moderately fatigue resistant, and type $2 \mathrm{~B}$ myofibers are fast twitch and not fatigue resistant. The proportions of these myofibers within skeletal muscles is dynamic and can change throughout life. $(2,17,36,37)$

Skeletal muscle is a highly complex and heterogeneous tissue serving a multitude of functions in the organism. Myogenesis or the process of generating muscle can be divided into several distinct phases.(38) During embryonic myogenesis, mesoderm-derived structures generate the first muscle fibers of the body proper, and in subsequent 


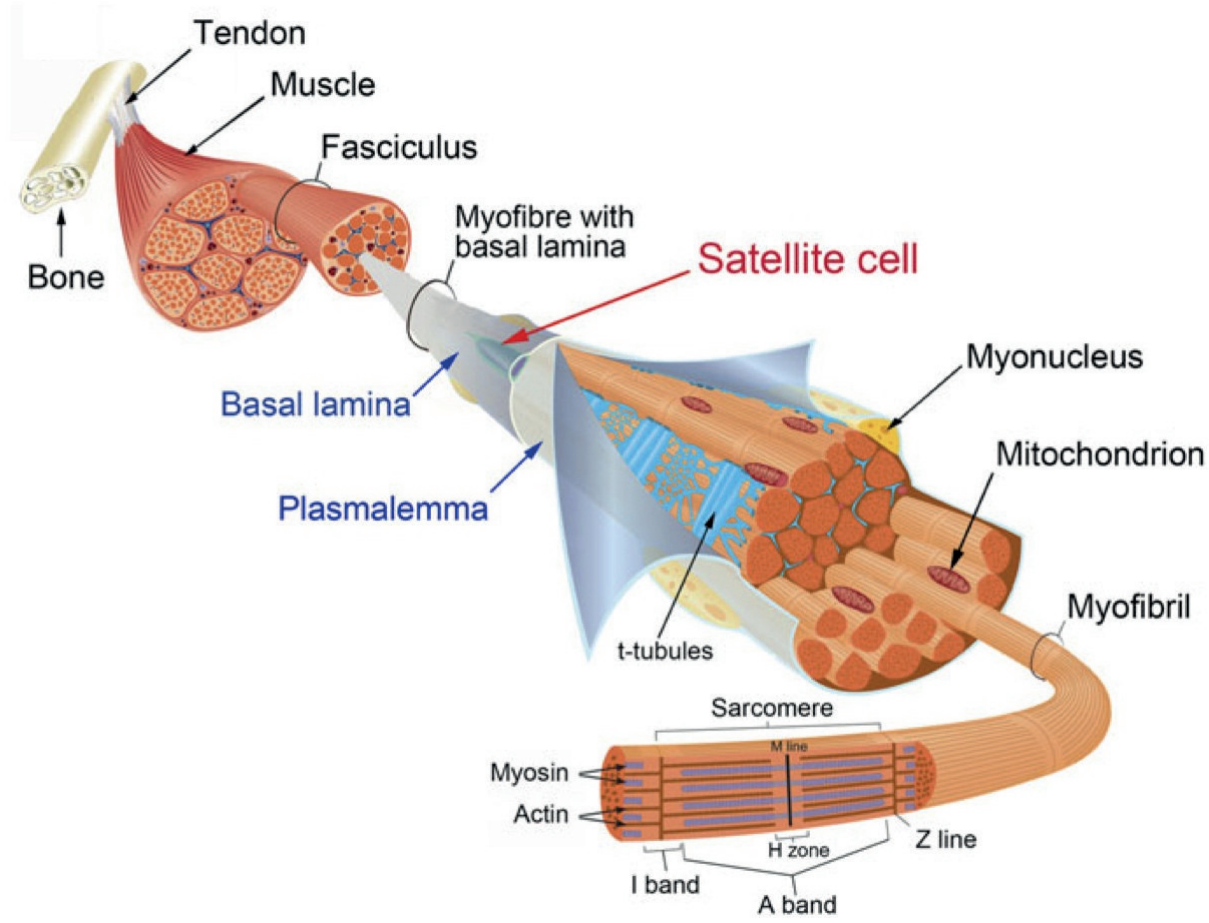

Figure 1. Muscle structure and the satellite cell niche. The structure and ultra-structure of skeletal muscle. (32) (Adapted with permission from The Company of Biologist, Ltd). waves additional fibers are generated along these template fibers. $(39,40)$ In the poorly understood perinatal phase, muscle resident myogenic progenitors initially proliferate extensively but later on decrease as the number of myonucle reaches a steady state and myofibrillar protein synthesis peaks. $(41,42)$ Once the muscle has matured, these progenitors will enter quiescence and henceforth reside within in it as satellite cells. Adult skeletal muscle, like all renewing organs, relies on a mechanism that compensates for the turnover of terminally differentiated cells to maintain tissue homeostasis. $(43,44)$ This type of myogenesis depends on the activation of satellite cells that have the potential to differentiate into new fibers.(17)

A broad spectrum of signaling molecules instructs myogenesis during embryonic development and in postnatal life. $(45,46)$ The activation of cell surface receptors by these signals induces intracellular pathways that ultimately converge on a battery of specific transcription and chromatinremodeling factors. These factors translate the extracellular signals into the gene and microRNA expression program, which assigns myogenic identity to the muscle progenitors. (47)

The healing of skeletal muscle in response to trauma depends on the type of injury such as contusion, strain, and laceration, and on the severity. However, in general, the healing process consists of three phases: the destruction phase, the repair phase, and the remodeling phase. $(2,17,21,36)$ The destruction phase is characterized by necrosis, hematoma formation, and the influx of inflammatory cells. During the repair phase, the necrotic debris is phagocytosed, and regeneration of myofibers occur through the action of satellite cells.(48,49) Firstly, quiescent satellite cells expressing paired box factors (Pax)7 migrate to the site of injury, up-regulate the myogenic regulatory factors (MRF) MyoD and Myf5, and become proliferative.(50-54) From now on, the satellite cells are also known as myoblasts. Subsequent differentiation of the myoblasts is marked by the down-regulation of Pax7 $(55,56)$ and up-regulation of the MRFs Mrf4 and Myogenin (50-52). Ultimately, these differentiated myoblasts form multinucleated myofibers (hyperplasia) or fuse to damaged myofibers (hypertrophy) for muscle regeneration.(17,34) During the last phase, the remodeling phase, the regenerated myofibers mature and contract. However, in some cases, reorganization and contraction of unstructured connective tissue occur, resulting in scar tissue and subsequent incomplete skeletal muscle regeneration. $(36,57,58)$

Next to skeletal muscle injury, diseases such as muscular dystrophy also lead to impaired muscle function. (59) Muscular dystrophy is characterized by muscle weakness and wasting. Many different forms of this disease have been identified. $(59,60)$ The most severe form is DMD, which is characterized by the absence of dystrophin.(61) Dystrophin is, together with other membrane-associated proteins, required for the structural integrity of the muscle fibers. The lack of dystrophin leads to membrane instability 
and tears in the sarcolemma of the muscle fibers.(62-64) This results in repeated cycles of muscle fiber necrosis and regeneration until the regenerative capacity is exhausted. Eventually the muscle fibers are mostly replaced by adipose and fibrous tissue.(65-67)

Macrophages exert either beneficial or deleterious effects on tissue repair, depending on their activation/ polarization state. They are crucial for adult skeletal muscle repair, notably by acting on myogenic precursor cells. Macrophages sequentially orchestrate adult myogenesis during regeneration of damaged skeletal muscle. These results support the emerging concept that inflammation, through macrophage activation, controls stem cell fate and coordinates tissue repair.(67)

A phenotypically and functionally distinct population of Treg cells that rapidly accumulated in the acutely injured skeletal muscle of mice, just as invading myeloidlineage cells switched from a proinflammatory to a proregenerative state. Muscle Treg cells expressed the growth factor Amphiregulin, which acted directly on muscle satellite cells in vitro and improved muscle repair in vivo. Thus, Treg cells and their products may provide new therapeutic opportunities for wound repair and muscular dystrophies. (68)

\section{Satellite Cells as Adult Muscle Stem Cells}

The skeletal muscle satellite cell was first described and named based on its anatomic location between the myofiber plasma and basement membranes. In 1961, two independent studies by Alexander Mauro and Bernard Katz provided the first electron microscopic descriptions of satellite cells in frog and rat muscles. These cells were soon detected in other vertebrates and acquired candidacy as the source of myogenic cells needed for myofiber growth and repair throughout life.(69)

Since the discovery of satellite cells, evidence has accumulated showing that they are the primary contributors to the postnatal growth, maintenance and repair of skeletal muscle. In adult muscle, satellite cells express the transcription factor Pax7 and remain quiescent under normal physiological conditions.(70,71) Readily responsive to molecular triggers from exercise, injuries or disease, satellite cells have a remarkable ability to self-renew, expand, proliferate as myoblasts or undergo myogenic differentiation to fuse and restore damaged muscle.(46) Most importantly, satellite cells are maintained through repeated cycles of growth and regeneration, which supports the notion that they are a heterogeneous population containing stem cells that sustain their self-renewal.(11) Thus with the evidence that satellite cells were capable of asymmetric divisions and endowed with self-renewal properties, a new era was born, in which satellite cells were considered bonafide muscle stem cells.(12)

It has long been postulated that satellite cells are the remnants of embryonic muscle development. Somitic progenitors that eventually give rise to satellite cells express Pax 3 and/or Pax7 and do not express MRF. These progenitor $\mathrm{Pax} 3^{+} \mathrm{Pax} 7^{+}$cells upregulate Myf5 and MyoD when they enter the myogenic differentiation programme, or remain as satellite cells during late fetal myogenesis without upregulating MRFs. $\mathrm{Pax} 3^{+} \mathrm{Pax}^{+}$cells that do not express MRFs are first found to align with nascent myotubes at embryonic day 15.5 and then become satellite cells by taking a sublaminar position.(72) Notably, once they arrive at the nascent myotubes, most satellite cells rapidly upregulate Myf5 and downregulate Pax3.(73) Lineagetracing studies suggest that $\mathrm{Pax}^{+}$cells contribute to embryonic myoblasts and the endothelial lineage, whereas $\mathrm{Pax}^{+}$cells contribute to fetal myoblasts, supporting the notion that these cells represent distinct myogenic lineages. (74) Therefore, satellite stem cells ( $\mathrm{Pax} 7^{+} \mathrm{Myf5}^{-}$) in adult muscle may represent a lineage continuum of the embryonic Pax $3^{+} \mathrm{Pax}^{+} \mathrm{MRF}^{-}$progenitors.(10) However, these studies have not conclusively ruled out the possibility that satellite cells are a distinct myogenic lineage, independent from those that give rise to fetal myoblasts, or that they arise from atypical myogenic stem cells in postnatal muscle.(11)

The identification of satellite cells by fluorescence microscopy relies on specific biomarkers. In adult skeletal muscle, all or most of satellite cells express the paired domain transcription factors Pax7 (70) and Pax3 (75), myogenic regulatory factor Myf5 (76), homeobox transcription factor Barx2 (77), cell adhesion protein M-cadherin (78), tyrosine receptor kinase c-Met (79), cell surface attachment receptor $\alpha 7$-intergin $(80,81)$, cluster of differentiation protein CD34 (53), transmembrane heparan sulfate proteoglycans syndecan-3 and syndecan-4 (82), chemokine receptor type 4 (CXCR4) (83), caveolae-forming protein caveolin-1 $(81,84)$, calcitonin receptor (85), and nuclear envelope proteins lamin $\mathrm{A} / \mathrm{C}$ and emerin (81). Of these, Pax7 is the canonical biomarker for satellite cells as it is specifically expressed in all quiescent and proliferating satellite cells (70) across multiple species, including human (86), monkey (86), mouse (70), pig (87), chick (88), salamander (89), frog (90), and zebrafish (91).

Skeletal muscle regeneration is a highly orchestrated process involving the activation of various cellular and 
molecular responses. As skeletal muscle stem cells, satellite cells play an indispensible role in this process. The selfrenewing proliferation of satellite cells not only maintains the stem cell population but also provides numerous myogenic cells, which proliferate, differentiate, fuse, and lead to new myofiber formation and reconstitution of a functional contractile apparatus. The complex behavior of satellite cells during skeletal muscle regeneration is tightly regulated through the dynamic interplay between intrinsic factors within satellite cells and extrinsic factors constituting the muscle stem cell niche/microenvironment.(92)

Muscular dystrophies are a heterogeneous group of devastating diseases characterized by progressive muscle weakness and degeneration (94), and currently there are no effective treatments. Currently, stem cellmediated therapeutic strategies such as muscle stem cell transplantation or functional enhancement of endogenous muscle stem cells are being pursued to improve muscle functions and pathology in muscular dystrophy patients. $(20,46,93,94)$ However, the development of effective therapies requires a better understanding of molecular and cellular mechanisms regulating muscle stem cell behaviors.

The progressive loss of muscle regenerative capacity with age or disease results in part from a decline in the number and function of satellite cells, the direct cellular contributors to muscle repair.(5-9,70,96-100) However, little is known about the molecular effectors underlying satellite cell impairment and depletion. Elevated levels of inflammatory cytokines, including interleukin-6 (IL-6), are associated with both age-related and muscle-wasting conditions.(101-104) The levels of signal transducer and activator of transcription 3 (STAT3), a downstream effector of IL-6, are also elevated with muscle wasting $(105,106)$, and STAT3 has been implicated in the regulation of selfrenewal and stem cell fate in several tissues (107-110). The effects of STAT3 inhibition on cell fate and proliferation were conserved in human myoblasts. The results of this study indicate that pharmacological manipulation of STAT3 activity can be used to counteract the functional exhaustion of satellite cells in pathological conditions, thereby maintaining the endogenous regenerative response and ameliorating muscle-wasting diseases.(111)

Skeletal muscle repair can be understood as a balance between fibrosis and regeneration, the result of which may lead to complete recovery or loss of muscle function. Activation of nitric oxide during muscle crush is critical in the early phases of the skeletal muscle repair process and indicates its possible role as a regulator of the balance between fibrosis and muscle regeneration.(112)

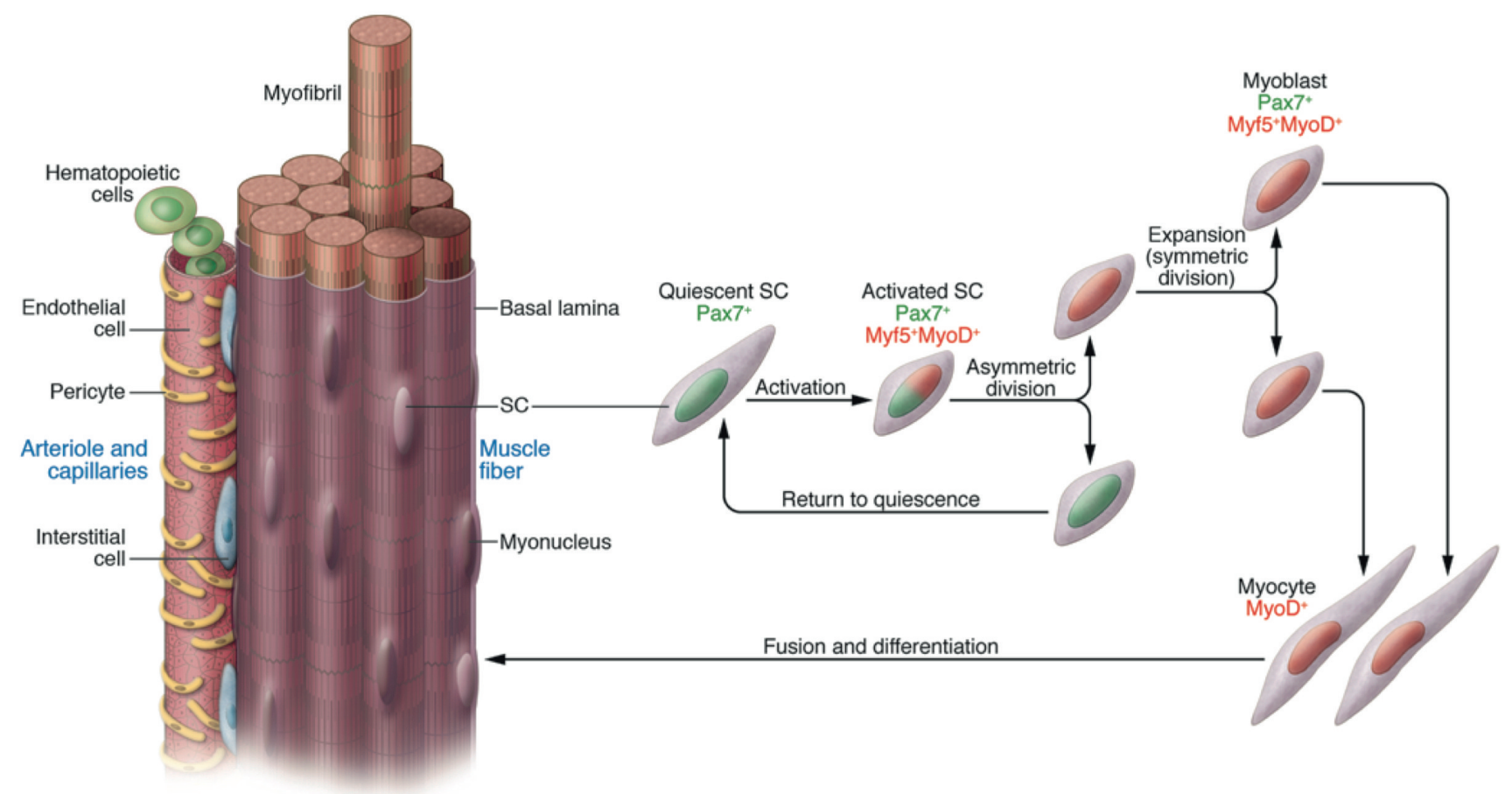

Figure 2. Asymmetric cell division during activation of satellite cells. This is a drawing representing the anatomy of a muscle fiber with adjacent small vessels. Satellite cells and other myogenic cells (pericytes and hematopoietic, endothelial, and interstitial cells) are depicted. Satellite cell activation in vivo is followed by an asymmetric division, with Pax7, MyoD, and Myf5 being expressed in differentiating cells and Pax7 in cells returning to quiescence in order to maintain a pool of progenitors.(114) (Adapted with permission from American Society for Clinical Investigation). 
The CXCR4/stromal cell-derived factor 1 (SDF1) axis is pivotal for efficient muscle regeneration after an episode of injury. In addition, it is possible that this system functions through matrix metalloproteinase (MMP)-10 activity where MMP-10 might regulate CXCR4/SDF1-mediated muscle repair via chemokine modulation. These findings suggest an important molecular mechanism that could be exploited to develop novel therapies for dystrophic diseases.(113)

Skeletal muscle damaged by injury or by degenerative diseases such as muscular dystrophy is able to regenerate new muscle fibers. Regeneration mainly depends upon satellite cells, myogenic progenitors localized between the basal lamina and the muscle fiber membrane. However, other cell types outside the basal lamina, such as pericytes, also have myogenic potency.

By learning more about satellite cells and other mesodermal skeletal muscle progenitors, we can learn how to better use them to repair muscle. The main limitations of satellite cells are loss of "stemness" upon culture and an inability to cross the vessel wall for systemic delivery. Limitations for other cell types are incomplete characterization and their overall minor myogenic potency. (114)

\section{The Satellite Cell Niche}

During the last half century, advances in molecular biology, cell biology, and genetics has greatly improved our understanding of skeletal muscle regeneration. In particular, extensive research on satellite cells and their niche has elucidated many cellular and molecular mechanisms that underlie skeletal muscle regeneration.(92) Based on the stem cell niche concept, behaviors of tissue-specific stem cells are determined by structural and biochemical cues emanating from the surrounding microenvironment.(115)

Similar to these adult stem cells, satellite cells are also present in a highly specified niche, which consists of the extracellular matrix (ECM), vascular and neural networks, different types of surrounding cells, and various diffusible molecules (Figure 3). Furthermore, satellite cells, as one of the niche components, also influence each other by means of cell-cell interaction and autocrine or paracrine signals. The dynamic interactions between satellite cells and their niche specifically regulate satellite cell quiescence, self-renewal, proliferation, and differentiation. In this fashion, muscle atrophy or excessive growth is prevented, and the satellite cell pool is maintained during regeneration. Understanding the interactions between satellite cells and their niche is of paramount importance for the development of therapies to treat both age-related skeletal muscle atrophy (sarcopenia) and skeletal muscle diseases.(92)

\section{Satellite cell: regulatory signaling pathways}

a. Wnt signaling.

Wnt signaling controls diverse biological processes, such as cell proliferation, cell fate determination, cell adhesion, cell polarity, and morphology. Wnt signaling is activated by binding of extracellular Wnt family glycoproteins with Frizzled receptors and low-density lipoprotein receptor-related protein (LRP5, LRP6) pairs. The Frizzled receptor can initiate two distinct signaling pathways: the $\mathrm{Wnt} / \beta$-catenin and $\mathrm{Wnt} /$ planar cell polarity (PCP) pathways. Wnt/ $\beta$-catenin pathway is characterized by the regulation of $\beta$-catenin stabilization and its entry into the nucleus. The Wnt/PCP pathway is involved in PCP and establishment of polarized cellular structures.(116)

b. Notch signaling.

Notch signaling regulates cell proliferation, differentiation, and cell fate determination.(117) Notch signaling plays key roles in skeletal muscle regeneration. (118) Upon muscle injury, the Notch ligand Delta is quickly upregulated in both activated satellite cells and in myofibers.(119) The upregulation of Delta in satellite cells is accompanied by the appearance of the Notch intracellular domain (NICD), indicative of activated Notch signaling. Activation of Notch signaling stimulates the proliferation of satellite cells and their progeny and thus leads to the expansion of proliferating myoblasts. Indeed, inhibition of Notch signaling abolishes satellite cell activation and impairs muscle regeneration.(119) In aged muscles, the expression of Notch in satellite cells remains unchanged. (120) However, the induction of Delta in myofibers is no longer responsive to muscle injury, which results in reduced satellite cell proliferation and impaired muscle regeneration. (120) In addition to its functions during muscle regeneration, Notch signaling is also involved in the maintenance of cell quiescence in resting health muscle.

The myofibers are the primary component of the satellite cell niche due to their direct contact with satellite cells. This suggested that the myofiber emanates a "quiescent" signal either by its physical association or by releasing chemical compounds. $(121,122)$ The basal lamina of the myofiber is composed of a network of ECM that directly contacts the satellite cell and separates it from the muscle interstitium. The basal lamina of skeletal muscle is composed of type IV collagen, laminin, entactin, fibronectin, perlecan, and decorin glycoproteins along with other proteoglycans.(123) These ECM molecules are mainly synthesized and excreted 

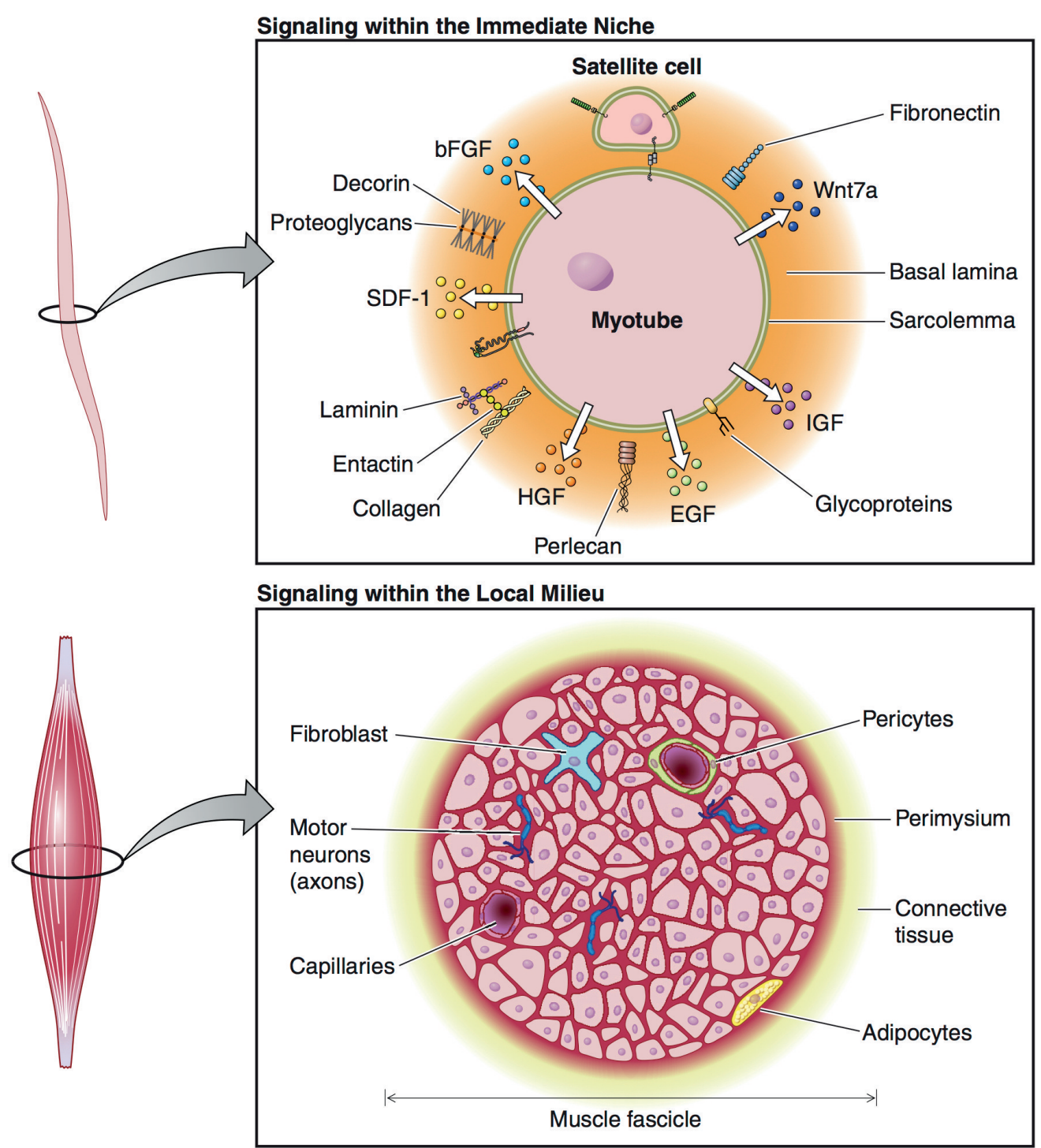

Signaling within the Systemic Milieu

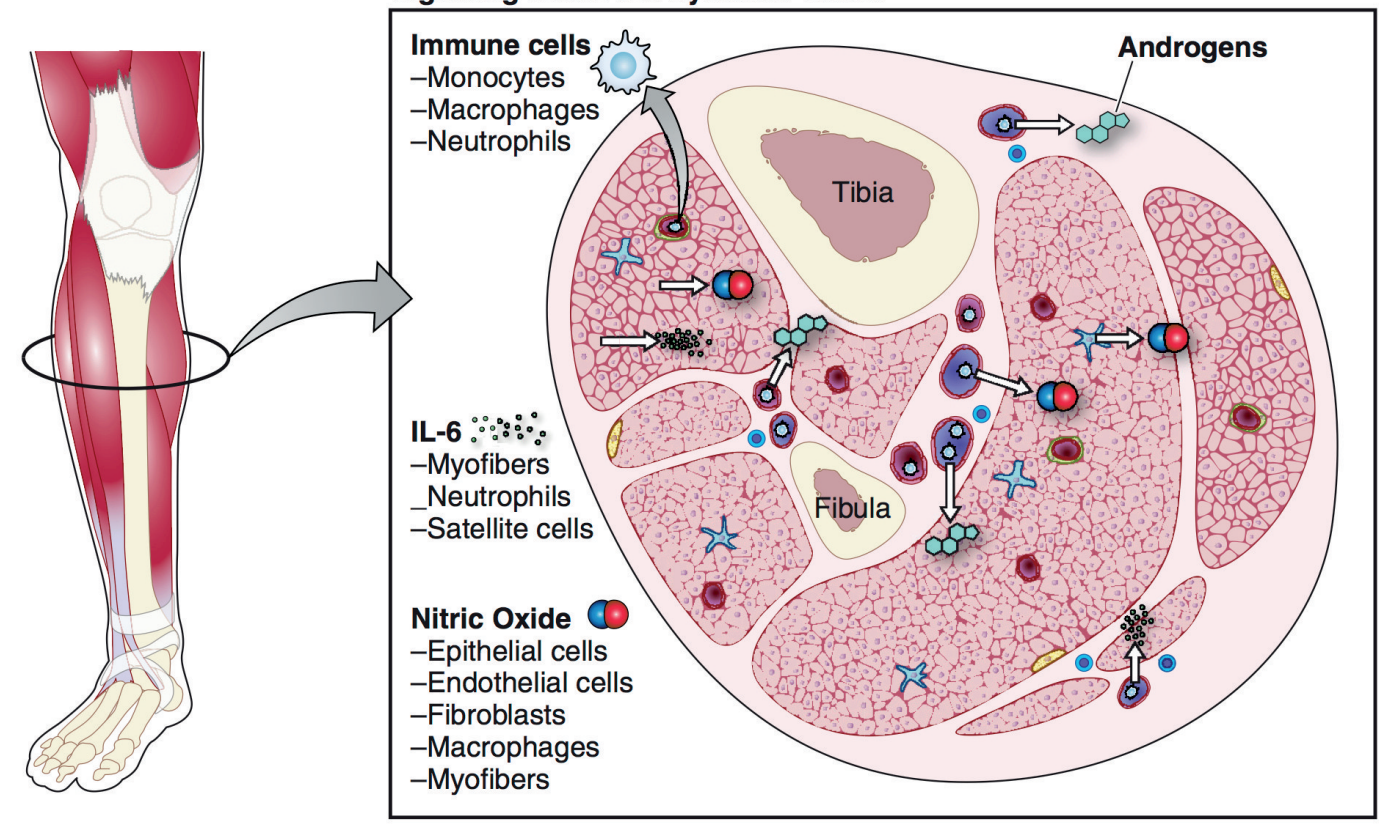

Figure 3.The satellite cell niche.(92) (Adapted with permission from the American physiological society). 
by interstitial fibroblasts but can also be produced and remodeled by myoblasts during muscle development and regeneration.(124) Satellite cells reside between the basal lamina, composed primarily of a type IV collagen network, and the apical sarcolemma covered in laminin.(125)

Proteoglycans reside on the surface of satellite cells and function as receptors to bind a suite of secreted, yet inactive growth factor precursors. These precursors, including hepatocyte growth factor (HGF) (126), basic fibroblast growth factor (bFGF) (127), epidermal growth factor (EGF) (128), insulin-like growth factor isoforms (IGF-I, IGF-II) (129) and various Wnt glycoproteins $(130,131)$, originated from either satellite cells, myofibers, interstitial cells, or serum. These growth factors can be swiftly rendered active by proteolytic enzymes present in serum or interstitium, such as thrombin, serine proteases, and MMPs. This highly coordinated process serves to stimulate satellite cell survival, activation, and proliferation upon muscle injury.(126,132-135)

Throughout regeneration, the hierarchical and collaborative behaviors of satellite cells are influenced by changes in their niche. These changes include diverse molecules, cells, and structures that constitute a dynamic niche continually influencing the multiple tasks set forth for satellite cells.(92)

\section{Skeletal Muscle Aging}

Satellite cells can self-renew, and it is this characteristic that allows adult skeletal muscle to undergo multiple rounds of regeneration without depleting their stem cell pool. $(8,10,56)$ However, the functional and structural decline of skeletal muscle in late adulthood is one of the first hallmarks of aging in many organisms. $(126,137,138)$ Notably, as an organism ages, a decrease in regenerative capacity is concomitant with a decrease in satellite cell numbers. $(139,140)$ The reduced regenerative potential observed in aging skeletal muscle is attributed primarily to changes in the muscle niche. Soluble ligands from the Notch, Wnt and transforming growth factor (TGF)- $\beta$ signaling pathways are deregulated both systemically and within the satellite cell niche. $(119,120,141,142)$ Alterations in the activity of these pathways in combination with fibrosis and an increased immune response result in age-related deficiencies in satellite cell self-renewal and regenerative efficacy.(143) Moreover, differences in satellite cell number and proliferative capacity have been noted in mouse and rat satellite cells isolated from the skeletal muscle of 3-monthold compared to 7 -month-old rodents.(140,144,145) Taken together, these findings indicate that age-related changes in satellite cell self-renewal, proliferative and differentiation capacity are likely due to both extrinsic alterations in the microenvironment and intrinsic alterations in cellautonomous regulatory mechanisms.(146)

Aged skeletal muscle undergoes a progressive reduction in the cross-sectional area of muscle fibers (147), selective loss of fast glycolytic fibers (148), and increase in muscle connective tissue (149). At the subcellular level, aged muscle fibers display an increased level of mitochondrial abnormalities and susceptibility to apoptosis. $(150,151)$ Myofibers from aged muscle show a reduction in force generation and are more susceptible to contraction-induced injury.(152) In addition to the immediate niche surrounding satellite cells, local interstitial cells, motor neurons, blood vessels, and their associated secretable factors reside within skeletal muscle and have the potential to regulate satellite cell function and affect muscle regeneration.

It is well known that denervation results in progressive skeletal muscle atrophy. During acute denervation of muscle, the percentage of satellite cells increases during the first week, indicating a proliferation phase similar to muscle injury.(153) However, long-term denervation results in a drastic decline in satellite cell numbers $(154,155)$, which is at least partially due to decreased mitotic capability and increased apoptosis of satellite cells. Taken together, these data indicate that neurotrophic factors function in an autocrine fashion to regulate satellite cell behavior and muscle regeneration. Thus it is conceivable that systematic release of neurotrophic factors after denervation may also exert similar regulatory roles on satellite cell activation and differentiation.

In aged muscle, examination of neuromuscular junctions by electron microscopy revealed decreases in nerve terminal area, mitochondria and synaptic vesicles, along with occasional denervated postsynaptic regions. (156) These changes, in addition to progressive myofiber atrophy, may potentially disturb signals between myofibers and satellite cells.

Skeletal muscle is nourished by the microvascular network. The importance of this niche component is reflected by the fact that most satellite cells are closely associated with capillaries in intact adult muscle.(157,158) It is also well known that angiogenesis and myogenesis proceed at the same time during muscle regeneration. Vascular endothelial growth factor (VEGF) plays an important role in satellite cell function and muscle regeneration.(159) In aged muscle, it was observed that while myofibers lose their close contact with the microvascular network, there is a corresponding 
VEGF level decrease.(160) In addition, endothelial nitric oxide synthase (eNOS) secreted by endothelial cells is also decreased in aged muscle.(161) Aged muscle displays a functional deficit in the immune cells surrounding the satellite cell niche. In vitro studies indicate that the capabilities of free radical generation, phagocytosis, and chemotaxis are decreased in aged immune cells.(162) The perturbation between satellite cells and immune cells impedes satellite cell activation and migration.

Satellite cells express androgen receptors and are receptive to androgen signaling (163), however, the endogenous androgens acting on satellite cells have yet to be determined. Exogenous testosterone increases satellite cell numbers by promoting satellite cell activation and proliferation. $(164,165)$ This function is predicted to involve the induction of Notch signaling in satellite cells.(165) During aging, systemic levels of androgens decline, which is concomitant with a loss in muscle mass and a gain in fat mass. $(166,167)$

Ectopic adipocyte deposition in the skeletal muscle characterizes various disorders, including obesity/type-2 diabetes, sarcopenia, and muscular dystrophies.(168-171) Progressive fat accumulation resulting in muscle weakness and atrophy $(172,173)$ is a measure of the severity of DMD (174). Stem cells ensure tissue regeneration, while overgrowth of adipogenic cells may compromise organ recovery and impair function. In myopathies and muscle atrophy associated with aging, fat accumulation increases dysfunction, and after chronic injury, the process of fatty degeneration, in which muscle is replaced by white

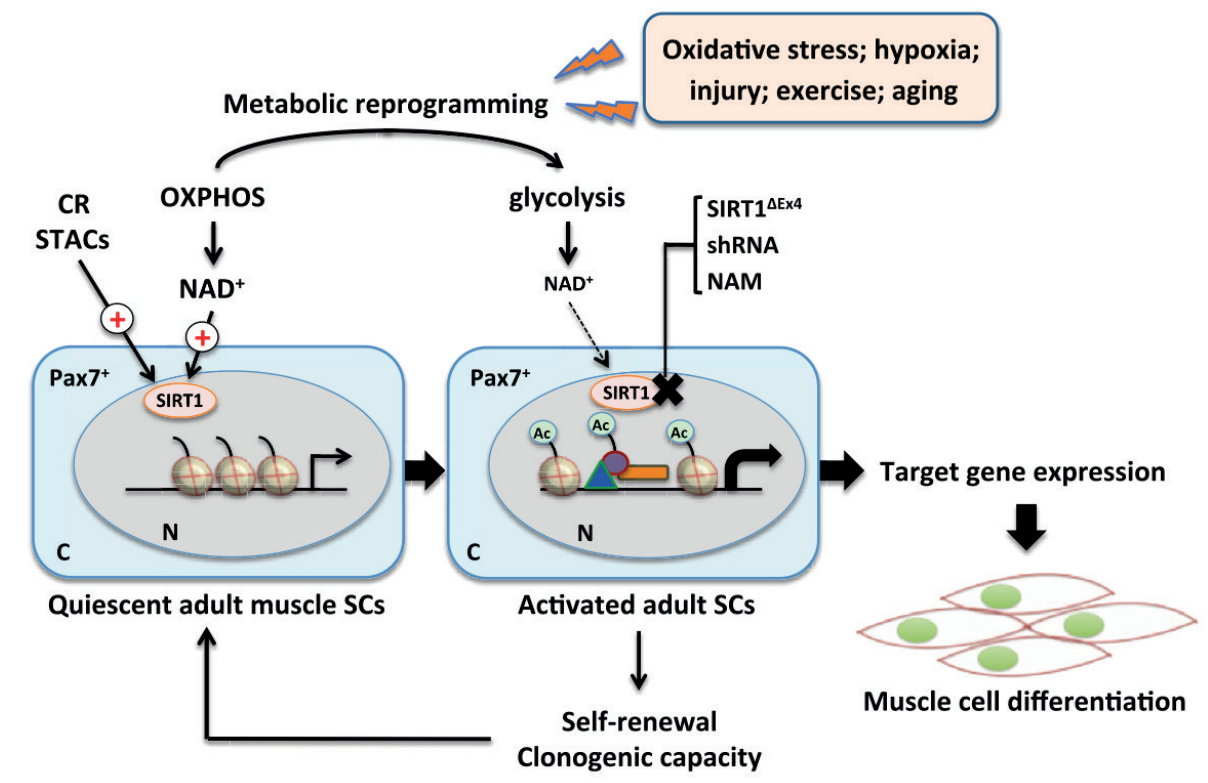

Figure 4. A Model on How Metabolic Reprogramming Promotes Satellite Cell Activation in Adult Skeletal Muscle.(180) (Adapted with permission from Cell Press). adipocytes, further compromises tissue function and environment. Some studies suggest that pericytes may contribute to muscle regeneration as well as fat formation. (175)

Satellite cells are currently not applicable to regenerative medicine due to difficulties in their isolation and loss of stemness ex vivo. However, satellite cell-based cell therapy would greatly benefit from future studies in lineage progression to better delineate satellite cell hierarchy along with physiologically relevant interactions between satellite cells and other myogenic cells. Moreover, such issues may be resolved following the maturation of techniques involving the generation of induced pluripotent stem- or other types of embryonic stem-like multipotent cells. If so, the broad interest of future studies should focus on identification of the intrinsic and extrinsic regulatory mechanisms that govern satellite cell commitment and differentiation throughout the muscle regeneration. Future advances in system biology and bioengineering may hopefully harness these previous achievements towards developing therapeutic approaches for sarcopenia and muscle dystrophic diseases.(92)

\section{Rejuvenating Aged Muscle Stem Cells}

Aging is accompanied by a decline in neuromuscular performance, skeletal muscle mass and stem cell function. $(176,177)$ Weakened muscles substantially increase the chance of injury, such as by falling. Because of the reduced regenerative capacity of aged tissues, recovery from such incidents and from subsequent surgical procedures is slow and possibly incomplete. Moreover, the inactivity associated with bed rest further accelerates muscle catabolism. These problems can lead to a vicious cycle of muscle loss, injury and inefficient repair, causing elderly patients to become increasingly sedentary over time. Thus, therapeutic strategies boosting muscle mass and regeneration in the aged are currently sought after.(178)

Skeletal muscle is a highly dynamic and metabolically active tissue that can self-repair in response to injury via the recruitment of muscle stem cells called satellite cells. Under normal conditions satellite cells, 
identified by the expression of the signature satellite cell marker Pax7 reside in a quiescent state between the basal lamina and the sarcolemma of the muscle fibers. Quiescent satellite cells have a low metabolic rate and display few active mitochondria and therefore are exposed to low levels of oxidative stress.(179) In response to muscle damage or injury (hypoxia, oxidative stress, inflammation, exercise, and aging), satellite cells become activated and trigger cellular reprogramming that results in enhanced proliferation, differentiation, and/or self-renewal (Figure 4).

Satellite cell activation requires a shift in the cellular metabolic state to better match their functional needs, a process referred as "metabolic reprogramming." Understanding the basic molecular mechanisms that govern myogenic stem cell fate constitutes an active research area with the aim of developing muscle stem cell therapies to improve muscle regeneration in a wide variety of neuromuscular disorders and age-related sarcopenia.(180)

Ryall and colleagues compare the transcriptome of quiescent and proliferating satellite cells and report that satellite cell activation is driven by a metabolic switch from fatty acid oxidation to glycolysis. This metabolic shift generates ATP while concomitantly lowering the cellular level of $\mathrm{NAD}^{+}$. In turn, reduced $\mathrm{NAD}^{+}$levels contribute to decreased nuclear Sirtuin (SIRT)1 deacetylase activity toward histone $\mathrm{H} 4$ acetylation at lysine 16 (H4K16). In a series of comprehensive and elegant experiments, the authors assess the role of SIRT1 in epigenetic regulation of satellite cell fate.(181) Overall, this study highlights the role of SIRT1 as a finely tuned biochemical sensor of the satellite cell metabolic state, supporting earlier reports that place SIRT1 at the crossroad between nutrient/energy homeostasis and cell fate signaling in skeletal muscle.(182)

Altogether, these findings provide evidence for the feasibility of targeting SIRT1 as an effective therapeutic intervention for the prevention or reversal of age-related sarcopenia and other degenerative muscle disorders. Encouraging results regarding the use of short-term calorie restriction, a dietary manipulation that increases SIRT1 activity (183), and synthetic small-molecule activators of SIRT1 (184) show muscle stem cell differentiation and improved muscle quality in laboratory animals.

\section{Conclusion}

During aging, skeletal muscle strength progressively declines (sarcopenia), leading to reduced mobility, muscle function and quality of life. Regenerative capacities of muscle stem cells, or satellite cells, decline with age. Extrinsic/ environmental cues have been implicated in this process, which is not surprising given the tight interactions muscle stem cells develop with the microenvironment, including immune cells. However, recent studies have shown that alterations in intrinsic cell signaling also contribute to the declined functionality of aged satellite cells.

With human longevity steadily increasing, strategies for the maintenance of muscle mass and its regenerative potential have great relevance for society and economy. The targeting of SIRT1-mediated epigenetic actions may prevent satellite cells dysfunction and would be an important strategy to achieve successful treatments for degenerative muscle diseases and sarcopenia.

\section{References}

1. Braun T, Gautel M. Transcriptional mechanisms regulating skeletal muscle differentiation, growth and homeostasis. Nat Rev Mol Cell Biol. 2011; 12: 349-61.

2. Huard J, Li Y, Fu FH. Muscle injuries and repair: current trends in research. J Bone Joint Surg Am. 2002; 84-A: 822-32.

3. Boldrin L, Morgan JE. Activating muscle stem cells: therapeutic potential in muscle diseases. Curr Opin Neurol. 2007; 20: 577-82.

4. Ten Broek RW, Grefte S, Von den Hoff JW. Regulatory factors and cell populations involved in skeletal muscle regeneration. J Cell Physiol. 2010; 224: 7-16.

5. Sambasivan R, Yao R, Kissenpfennig A, Van Wittenberghe L, Paldi A, Gayraud-Morel B, et al. Pax7-expressing satellite cells are indispensable for adult skeletal muscle regeneration. Development. 2011; 138: 3647-56.

6. Lepper C, Partridge TA, Fan CM. An absolute requirement for Pax7positive satellite cells in acute injury-induced skeletal muscle regeneration. Development. 2011; 138: 3639-46.

7. Murphy MM, Lawson JA, Mathew SJ, Hutcheson DA, Kardon G. Satellite cells, connective tissue fibroblasts and their interactions are crucial for muscle regeneration. Development. 2011; 138: 3625-37.

8. Collins CA, Olsen I, Zammit PS, Heslop L, Petrie A, Partridge TA, et al. Stem cell function, self-renewal, and behavioral heterogeneity of cells from the adult muscle satellite cell niche. Cell. 2005; 122: 289-301.

9. Montarras D, Morgan J, Collins C, Relaix F, Zaffran S, Cumano A, et al. Direct isolation of satellite cells for skeletal muscle regeneration. Science. 2005; 309: 2064-7.

10. Kuang S, Kuroda K, Le Grand F, Rudnicki MA. Asymmetric selfrenewal and commitment of satellite stem cells in muscle. Cell. 2007; 129: 999-1010.

11. Wang YX, Rudnicki MA. Satellite cells, the engines of muscle repair. Nat Rev Mol Cell Biol. 2011; 13: 127-33.

12. Brack AS, Rando TA. Tissue-specific stem cells: lessons from the skeletal muscle satellite cell. Cell Stem Cell. 2012; 10: 504-14.

13. Kuang S, Rudnicki MA. The emerging biology of satellite cells and their therapeutic potential. Trends Mol Med. 2008; 14: 82-91.

14. Shan T, Zhang P, Liang X, Bi P, Yue F, Kuang S. Lkb1 is indispensable for skeletal muscle development, regeneration, and satellite cell homeostasis. Stem Cells. 2014; 32: 2893-907.

15. Mauro A. Satellite cell of skeletal muscle fibers. J Biophys Biochem Cytol. 1961; 9: 493-5. 
16. Muir AR, Kanji AH, Allbrook D. The structure of the satellite cells in skeletal muscle. J Anat. 1965; 99: 435-44.

17. Chargé SB, Rudnicki MA. Cellular and molecular regulation of muscle regeneration. Physiol Rev. 2004; 84: 209-38.

18. Buckingham ME. Myogenic progenitor cells and skeletal myogenesis in vertebrates. Curr Opin Genet Dev. 2006; 16: 525-32.

19. Chen JC, Goldhamer DJ. Skeletal muscle stem cells. Reprod Biol Endocrinol. 2003; 1: 101-7.

20. Shi X, Garry DJ. Muscle stem cells in development, regeneration, and disease. Genes Dev. 2006; 20: 1692-708.

21. Grefte S, Kuijpers-Jagtman AM, Torensma R, Von den Hoff JW. Skeletal muscle development and regeneration. Stem Cell Dev. 2007; 16: 857-68.

22. Doherty TJ. Invited review: aging and sarcopenia. J Appl Physiol. 2003; 95: 1717-27.

23. Doherty TJ. The influence of aging and sex on skeletal muscle mass and strength. Curr Opin Clin Nutr Metab Care. 2001; 4: 503-8.

24. Doherty TJ, Vandervoort AA, Brown WF. Effects of ageing on the motor unit: a brief review. Can J Appl Physiol. 1993; 18: 331-58.

25. Berger MJ, Doherty TJ. Sarcopenia: prevalence, mechanisms, and functional consequences. Interdiscipl Top Gerontol. 2010; 37: 94114.

26. Carlson ME, Suetta C, Conboy MJ, Aagaard P, Mackey A, Kjaer M, et al. Molecular aging and rejuvenation of human muscle stem cells. EMBO Mol Med. 2009; 1: 381-91.

27. Ehler E, Gautel M. The sarcomere and sarcomerogenesis. Adv Exp Med Biol. 2008; 642: 1-14.

28. Lange S, Ehler E, Gautel M. From A to Z and back? Multicompartment proteins in the sarcomere. Trends Cell Biol. 2006; 16: 11-8.

29. Pette D, Staron RS. Myosin isoforms, muscle fiber types, and transitions. Microsc Res Tech. 2000; 50: 500-9.

30. Schiaffino S. Fibre types in skeletal muscle: a personal account. Acta Physiol (Oxf). 2010; 199: 451-63.

31. Janssen I, Heymsfield SB, Wang ZM, Ross R. Skeletal muscle mass and distribution in 468 men and women aged 18-88 yr. J Appl Physiol. 2000; 89: 81-8.

32. Relaix F, Zammit PS. Satellite cells are essential for skeletal muscle regeneration: the cell on the edge returns centre stage. Development. 2012; 139: 3845-56.

33. Katz B. The terminations of the afferent nerve fibre in the muscle spindle of the frog. Philos Trans R Soc Lond (Biol). 1961; 243: 22140.

34. Hawke TJ, Garry DJ. Myogenic satellite cells: physiology to molecular biology. J Appl Physiol. 2001; 91: 534-51.

35. Yablonka-Reuveni Z, Day K. Skeletal muscle stem cells in the spotlight: the satellite cell. In: Cohen I, Gaudette G, editors. Regenerating the Heart: Stem Cells and the Cardiovascular System. New York: Springer, Humana Press; 2011. p.173-200.

36. Järvinen TA, Järvinen TL, Kääriäinen $M$, Kalimo $H$, Järvinen $M$. Muscle injuries: biology and treatment. Am J Sports Med. 2005; 33 : 745-64.

37. Brooks SV. Current topics for teaching skeletal muscle physiology. Adv Physiol Educ. 2003; 27: 171-82.

38. Tajbakhsh S. Skeletal muscle stem cells in developmental versus regenerative myogenesis. J Intern Med. 2009; 266: 372-89.

39. Parker MH, Seale P, Rudnicki MA. Looking back to the embryo: defining transcriptional networks in adult myogenesis. Nat Rev Genet. 2003; 4: 497-507.

40. Sambasivan R, Tajbakhsh S. Skeletal muscle stem cell birth and properties. Semin Cell Dev Biol. 2007; 18: 870-82.

41. Schultz E. Satellite cell proliferative compartments in growing skeletal muscles. Dev Biol. 1996; 175: 84-94.
42. Davis TA, Fiorotto ML. Regulation of muscle growth in neonates. Curr Opin Clin Nutr Metab Care. 2009; 12: 78-85.

43. Schmalbruch H, Lewis DM. Dynamics of nuclei of muscle fibers and connective tissue cells in normal and denervated rat muscles. Muscle Nerve. 2000; 23: 617-26.

44. Pellettieri J, Sanchez Alvarado A. Cell turnover and adult tissue homeostasis: from humans to planarians. Annu Rev Genet. 2007; 41: 83-105.

45. Kuang S, Gillespie MA, Rudnicki MA. Niche regulation of muscle satellite cell self-renewal and differentiation. Cell Stem Cell. 2008; 2: 22-31.

46. Bentzinger CF, von Maltzahn J, Rudnicki MA. Extrinsic regulation of satellite cell specification. Stem Cell Res Ther. 2010; 1: 27. doi: $10.1186 /$ scrt27.

47. Bentzinger CF, Wang YX, Rudnicki MA. Building muscle: molecular regulation of myogenesis. Cold Spring Harb Perspect Biol. 2012; 4: a008342. doi: 10.1101/cshperspect.a008342.

48. Wozniak AC, Kong J, Bock E, Pilipowicz O, Anderson JE. Signaling satellite-cell activation in skeletal muscle: markers, models, stretch, and potential alternate pathways. Muscle Nerve. 2005; 31: 283-300.

49. Zammit PS, Partridge TA, Yablonka-Reuveni Z. The skeletal muscle satellite cell: the stem cell that came in from the cold. J Histochem Cytochem. 2006; 54: 1177-91.

50. Cornelison DD, Wold BJ. Single-cell analysis of regulatory gene expression in quiescent and activated mouse skeletal muscle satellite cells. Dev Biol. 1997; 191: 270-83.

51. Smith CK, Janney MJ, Allen RE. Temporal expression of myogenic regulatory genes during activation, proliferation, and differentiation of rat skeletal muscle satellite cells. J Cell Physiol. 1994; 159: 37985.

52. Yablonka-Reuveni Z, Rivera AJ. Temporal expression of regulatory and structural muscle proteins during myogenesis of satellite cells on isolated adult rat fibers. Dev Biol. 1994; 164: 588-603.

53. Beauchamp JR, Heslop L, Yu DS, Tajbakhsh S, Kelly RG, Wernig A, et al. Expression of CD34 and Myf5 defines the majority of quiescent adult skeletal muscle satellite cells. J Cell Biol. 2000; 151: 1221-34.

54. Cooper RN, Tajbakhsh S, Mouly V, Cossu G, Buckingham M, ButlerBrowne GS. In vivo satellite cell activation via Myf5 and MyoD in regenerating mouse skeletal muscle. J Cell Sci. 1999; 112: 2895 901.

55. Olguin HC, Olwin BB. Pax-7 up-regulation inhibits myogenesis and cell cycle progression in satellite cells: a potential mechanism for self-renewal. Dev Biol. 2004; 275: 375-88.

56. Zammit PS, Golding JP, Nagata Y, Hudon V, Partridge TA, Beauchamp JR. Muscle satellite cells adopt divergent fates: a mechanism for self-renewal? J Cell Biol. 2004; 166: 347-57.

57. Kääriäinen $M$, Järvinen $T$, Järvinen $M$, Rantanen J, Kalimo $H$. Relation between myofibers and connective tissue during muscle injury repair. Scand J Med Sci Sports. 2000; 10: 332-7.

58. Kasemkijwattana C, Menetrey J, Somogyl G, Moreland MS, Fu FH, Buranapanitkit B, et al. Development of approaches to improve the healing following muscle contusion. Cell Transplant. 1998; 7: 58598.

59. Muir LA, Chamberlain JS. Emerging strategies for cell and gene therapy of the muscular dystrophies. Expert Rev Mol Med. 2009; 11: e18. doi: 10.1017/S1462399409001100.

60. Bansal D, Campbell KP. Dysferlin and the plasma membrane repair in muscular dystrophy. Trends Cell Biol. 2004; 14: 206-13.

61. Hoffman EP, Brown RH Jr, Kunkel LM. Dystrophin: the protein product of the Duchenne muscular dystrophy locus. Cell. 1987; 51: 919-28. 
62. Batchelor CL, Winder SJ. Sparks, signals and shock absorbers: how dystrophin loss causes muscular dystrophy. Trends Cell Biol. 2006; 16: $198-205$

63. Matsumura K, Campbell KP. Dystrophin-glycoprotein complex: its role in the molecular pathogenesis of muscular dystrophies. Muscle Nerve. 1994; 17: 2-15.

64. Ozawa E, Yoshida M, Suzuki A, Mizuno Y, Hagiwara Y, Noguchi S. Dystrophin-associated proteins in muscular dystrophy. Hum Mol Genet. 1995: 4 Spec No: 1711-6.

65. Bell CD, Conen PE. Histopathological changes in Duchenne muscular dystrophy. J Neurol Sci. 1968; 7: 529-44.

66. Briguet A, Courdier-Fruh I, Foster M, Meier T, Magyar JP. Histological parameters for the quantitative assessment of muscular dystrophy in the mdx-mouse. Neuromuscul Disord. 2004; 14: 67582.

67. DiMario JX, Uzman A, Strohman RC. Fiber regeneration is not persistent in dystrophic (MDX) mouse skeletal muscle. Dev Biol. 1991; 148: 314-21.

68. Saclier M, Yacoub-Yousef H, Mackey AL, Armold L, Ardjoune H, Magnan M, et al. Differentially activated macrophages orchestrate myogenic precursor cell fate during human skeletal muscle regeneration. Stem Cells. 2013; 31: 384-96.

69. Burzyn D, Kuswanto W, Kolodin D, Shadrach JL, Cerletti M, Jang Y, et al. A special population of regulatory $\mathrm{T}$ cells potentiates muscle repair. Cell. 2013; 155: 1282-95.

70. Yablonka-Reuveni $Z$. The skeletal muscle satellite cell: still young and fascinating at 50. J Histochem Cytochem. 2011; 59: 1041-59.

71. Seale P, Sabourin LA, Girgis-Gabardo A, Mansouri A, Gruss P, Rudnicki MA. Pax7 is required for the specification of myogenic satellite cells. Cell. 2000; 102: 777-86.

72. Schult E, Gibson MC, Champion T. Satellite cells are mitotically quiescent in mature mouse muscle: an EM and radioautographic study. J Exp Zool. 1978; 206: 451-6.

73. Relaix F, Rocancourt D, Mansouri A, Buckingham M. A Pax3/Pax7dependent population of skeletal muscle progenitor cells. Nature. 2005; 435: 948-53.

74. Kassar-Duchossoy L, Giacone E, Gayraud-Morel B, Jory A, Gomès D, Tajbakhsh S. Pax3/Pax7 mark a novel population of primitive myogenic cells during development. Genes Dev. 2005; 19: 1426-31.

75. Hutcheson DA, Zhao J, Merrell A, Haldar M, Kardon G. Embryonic and fetal limb myogenic cells are derived from developmentally distinct progenitors and have different requirements for $\beta$-catenin. Genes Dev. 2009; 23: 997-1013.

76. Buckingham M, Bajard L, Chang T, Daubas P, Hadchouel J, Meilhac $\mathrm{S}$, et al. The formation of skeletal muscle: from somite to limb. J Anat. 2003; 202: 59-68.

77. Cornelison DD, Wold BJ. Single-cell analysis of regulatory gene expression in quiescent and activated mouse skeletal muscle satellite cells. Dev Biol. 1997; 191: 270-83.

78. Meech R, Gonzalez KN, Barro M, Gromova A, Zhuang L, Hulin JA, et al. Barx2 is expressed in satellite cells and is required for normal muscle growth and regeneration. Stem Cells. 2012; 30: 253-65.

79. Irintchev A, Zeschnigk M, Starzinski-Powitz A, Wernig A. Expression pattern of M-cadherin in normal, denervated, and regenerating mouse muscles. Dev Dyn. 1994; 199: 326-37.

80. Allen RE, Sheehan SM, Taylor RG, Kendall TL, Rice GM. Hepatocyte growth factor activates quiescent skeletal muscle satellite cells in vitro. J Cell Physiol. 1995; 165: 307-12.

81. Burkin DJ, Kaufman SJ. The alpha7beta1 integrin in muscle development and disease. Cell Tissue Res. 1999; 296: 183-90.

82. Gnocchi VF, White RB, Ono Y, Ellis JA, Zammit PS. Further characterisation of the molecular signature of quiescent and activated mouse muscle satellite cells. PLoS One. 2009; 4: e5205. doi: 10.1371/journal.pone.0005205.

83. Cornelison DD, Filla MS, Stanley HM, Rapraeger AC, Olwin BB. Syndecan-3 and syndecan-4 specifically mark skeletal muscle satellite cells and are implicated in satellite cell maintenance and muscle regeneration. Dev Biol. 2001; 239: 79-94.

84. Ratajczak MZ, Majka M, Kucia M, Drukala J, Pietrzkowski Z, Peiper $\mathrm{S}$, et al. Expression of functional CXCR4 by muscle satellite cells and secretion of SDF-1 by muscle-derived fibroblasts is associated with the presence of both muscle progenitors in bone marrow and hematopoietic stem/progenitor cells in muscles. Stem Cells. 2003; 21: 363-71.

85. Volonte D, Liu Y, Galbiati F. The modulation of caveolin-1 expression controls satellite cell activation during muscle repair. FASEB J. 2005; 19: 237-9.

86. Fukada S, Uezumi A, Ikemoto M, Masuda S, Segawa M, Tanimura N, et al. Molecular signature of quiescent satellite cells in adult skeletal muscle. Stem Cells. 2007; 25: 2448-59.

87. McLoon LK, Wirtschafter J. Activated satellite cells in extraocular muscles of normal adult monkeys and humans. Invest Ophthalmol Vis Sci. 2003; 44: 1927-32.

88. Patruno M, Caliaro F, Martinello T, Mascarello F. Expression of the paired box domain Pax 7 protein in myogenic cells isolated from the porcine semitendinosus muscle after birth. Tissue Cell. 2008; 40: $1-6$.

89. Halevy O, Piestun Y, Allouh MZ, Rosser BW, Rinkevich Y, Reshef R, et al. Pattern of Pax 7 expression during myogenesis in the posthatch chicken establishes a model for satellite cell differentiation and renewal. Dev Dyn. 2004; 231: 489-502.

90. Morrison JI, Loof S, He P, Simon A. Salamander limb regeneration involves the activation of a multipotent skeletal muscle satellite cell population. J Cell Biol. 2006; 172: 433-40.

91. Chen Y, Lin G, Slack JM. Control of muscle regeneration in the Xenopus tadpole tail by Pax7. Development. 2006; 133: 2303-13.

92. Hammond CL, Hinits Y, Osborn DP, Minchin JE, Tettamanti G, Hughes SM. Signals and myogenic regulatory factors restrict Pax3 and Pax7 expression to dermomyotome-like tissue in zebrafish. Dev Biol. 2007; 302: 504-21.

93. Yin H, Price F, Rudnicky MA. Satellite cells and the muscle stem cell niche. Physiol Rev. 2013; 93: 23-67.

94. Wallace GQ, McNally EM. Mechanisms of muscle degeneration, regeneration, and repair in the muscular dystrophies. Annu Rev Physiol. 2009; 71: 37-57.

95. Quattrocelli M, Cassano M, Crippa S, Perini I, Sampaolesi M. Cell therapy strategies and improvements for muscular dystrophy. Cell Death Differ. 2010; 17: 1222-9.

96. Lin S, Shen H, Jin B, Gu Y, Chen Y, Cao C, et al. Brief report: Blockade of Notch signaling in muscle stem cells causes muscular dystrophic phenotype and impaired muscle regeneration. Stem Cells. 2013; 31: 823-8.

97. Sacco A, Doyonnas R, Kraft P, Vitorovic S, Blau HM. Self-renewal and expansion of single transplanted muscle stem cells. Nature. 2008; 456: 502-6.

98. Cerletti M, Jurga S, Witczak CA, Hirshman MF, Shadrach JL, Goodyear LJ, et al. Highly efficient, functional engraftment of skeletal muscle stem cells in dystrophic muscles. Cell. 2008; 134: $37-47$.

99. Sacco A, Mourkioti F, Tran R, Choi J, Llewellyn M, Kraft P, et al. Short telomeres and stem cell exhaustion model Duchenne muscular dystrophy in mdx/mTR mice. Cell. 2010; 143: 1059-71.

100. Chakkalakal JV, Jones KM, Basson MA, Brack AS. The aged niche disrupts muscle stem cell quiescence. Nature. 2012; 490: 355-60. 
101. Sousa-Victor P, Gutarra S, García-Prat L, Rodriguez-Ubreva J, Ortet L, Ruiz-Bonilla V, et al. Geriatric muscle stem cells switch reversible quiescence into senescence. Nature. 2014; 506: 316-21.

102. Tidball JG. Inflammatory processes in muscle injury and repair. Am J Physiol Regul Integr Comp Physiol. 2005; 288: R345-53.

103. Fearon KC, Glass DJ, Guttridge DC. Cancer cachexia: mediators, signaling, and metabolic pathways. Cell Metab. 2012; 16: 153-66.

104. Strassmann G, Fong M, Kenney JS, Jacob CO. Evidence for the involvement of interleukin 6 in experimental cancer cachexia. J Clin Invest. 1992; 89: 1681-4.

105. Bonetto A, Aydogdu T, Kunzevitzky N, Guttridge DC, Khuri S, Koniaris LG, et al. STAT3 activation in skeletal muscle links muscle wasting and the acute phase response in cancer cachexia. PLoS ONE. 2011; 6: e22538. doi: 10.1371/journal.pone.0022538.

106. Muñoz-Cánoves P, Scheele C, Pedersen BK, Serrano AL. Interleukin-6 myokine signaling in skeletal muscle: a double-edged sword? FEBS J. 2013; 280: 4131-48.

107. Zhang L, Pan J, Dong Y, Tweardy DJ, Dong Y, Garibotto G, et al. Stat3 activation links a C/EBP $\delta$ to myostatin pathway to stimulate loss of muscle mass. Cell Metab. 2013; 18: 368-79.

108. Kiger AA, Jones DL, Schulz C, Rogers MB, Fuller MT. Stem cell self-renewal specified by JAK-STAT activation in response to a support cell cue. Science. 2001; 294: 2542-5.

109. Tulina N, Matunis E. Control of stem cell self-renewal in Drosophila spermatogenesis by JAK-STAT signaling. Science. 2001; 294: 2546-9.

110. Oh IH, Eaves CJ. Overexpression of a dominant negative form of STAT3 selectively impairs hematopoietic stem cell activity. Oncogene. 2002; 21: 4778-87.

111. Doles J, Storer M, Cozzuto L, Roma G, Keyes WM. Age-associated inflammation inhibits epidermal stem cell function. Genes Dev. 2012; 26: 2144-53.

112. Tierney MT, Aydogdu T, Sala D, Malecova B, Gatto S, Puri PL, et al. STAT3 signaling controls satellite cell expansion and skeletal muscle repair. Nat Med. 2014; 20: 1182-6.

113. Filippin LI, Cuevas MJ, Lima E, Marroni NP, Gonzales-Gallego J, Xavier RM. Nitric oxide regulates the repair of injured skeletal muscle. Nitric Oxide. 2011; 24: 43-9.

114. Bobadilla M, Sainz N, Abidanza G, Orbe J, Rodriguez JA, Paramo JA, et al. The CXCR4/SDF1 axis improves muscle regeneration through MMP-10 activity. Stem Cells Dev. 2014; 23: 1417-27.

115. Tedesco FS, Dellavalle A, Diaz-Manera J, Messina G, Cossu G. Repairing skeletal muscle: regenerative potensial of skeletal muscle stem cells. J Clin Invest. 2010; 120: 11-9.

116. Ohlstein B, Kai T, Decotto E, Spradling A. The stem cell niche: theme and variations. Curr Opin Cell Biol. 2004; 16: 693-9.

117. Gao C, Chen YG. Dishevelled: the hub of Wnt signaling. Cell Signal. 2010; 22: 717-27.

118. Artavanis-Tsakonas S, Rand MD, Lake RJ. Notch signaling: cell fate control and signal integration in development. Science. 1999; 284 : 770-6.

119. Luo D, Renault VM, Rando TA. The regulation of Notch signaling in muscle stem cell activation and postnatal myogenesis. Semin Cell Dev Biol. 2005; 16: 612-22.

120. Conboy IM, Rando TA. The regulation of Notch signaling controls satellite cell activation and cell fate determination in postnatal myogenesis. Dev Cell. 2002; 3: 397-409.

121. Conboy IM, Conboy MJ, Smythe GM, Rando TA. Notch-mediated restoration of regenerative potential to aged muscle. Science. 2003; 302: 1575-7.

122. Bischoff R. Interaction between satellite cells and skeletal muscle fibers. Development. 1990; 109: 943-52.
123. Bischoff R. A satellite cell mitogen from crushed adult muscle. Dev Biol. 1986; 115: 140-7.

124. Sanes JR. The basement membrane/basal lamina of skeletal muscle. J Biol Chem. 2003; 278: 12601-4.

125. Kovanen V. Intramuscular extracellular matrix: complex environment of muscle cells. Exerc Sport Sci Rev. 2002; 30: 20-5.

126. Woodley DT, Rao CN, Hassell JR, Liotta LA, Martin GR, Kleinman HK. Interactions of basement membrane components. Biochim Biophys Acta. 1983; 761: 278-83.

127. Tatsumi R, Anderson JE, Nevoret CJ, Halevy O, Allen RE. HGF/SF is present in normal adult skeletal muscle and is capable of activating satellite cells. Dev Biol. 1998; 194: 114-28.

128. DiMario J, Buffinger N, Yamada S, Strohman RC. Fibroblast growth factor in the extracellular matrix of dystrophic (mdx) mouse muscle. Science. 1989; 244: 688-90.

129. Golding JP, Calderbank E, Partridge TA, Beauchamp JR. Skeletal muscle stem cells express anti-apoptotic ErbB receptors during activation from quiescence. Exp Cell Res. 2007; 313: 341-56.

130. Machida S, Booth FW. Insulin-like growth factor 1 and muscle growth: implication for satellite cell proliferation. Proc Nutr Soc. 2004; 63: 337-40.

131. Brack AS, Conboy IM, Conboy MJ, Shen J, Rando TA. A temporal switch from notch to Wnt signaling in muscle stem cells is necessary for normal adult myogenesis. Cell Stem Cell. 2008; 2: 50-9.

132. Le Grand F, Jones AE, Seale V, Scime A, Rudnicki MA. Wnt7a activates the planar cell polarity pathway to drive the symmetric expansion of satellite stem cells. Cell Stem Cell. 2009; 4: 535-47.

133. Jenniskens GJ, Veerkamp JH, van Kuppevelt TH. Heparan sulfates in skeletal muscle development and physiology. J Cell Physiol. 2006; 206: 283-94.

134. Langsdorf A, Do AT, Kusche-Gullberg M, Emerson CP Jr, Ai X. Sulfs are regulators of growth factor signaling for satellite cell differentiation and muscle regeneration. Dev Biol. 2007; 311: 46477.

135. Olwin BB, Rapraeger A. Repression of myogenic differentiation by aFGF, bFGF, and K-FGF is dependent on cellular heparan sulfate. J Cell Biol. 1992; 118: 631-9.

136. Yamada M, Tatsumi R, Kikuiri T, Okamoto S, Nonoshita S, Mizunoya $\mathrm{W}$, et al. Matrix metalloproteinases are involved in mechanical stretch-induced activation of skeletal muscle satellite cells. Muscle Nerve. 2006; 34: 313-9.

137. Carlson ME, Conboy IM. Loss of stem cell regenerative capacity within aged niches. Aging Cell. 2007; 6: 371-82.

138. Augustin H, Partridge L. Invertebrate models of age-related muscle degeneration. Biochim Biophys Acta. 2009; 1790: 1084-94.

139. Grounds MD. Age-associated changes in the response of skeletal muscle cells to exercise and regeneration. Ann NY Acad Sci. 1998; 854: 78-91.

140. Allbrook DB, Han MF, Hellmuth AE. Population of muscle satellite cells in relation to age and mitotic activity. Pathology. 1971; 3: 22343.

141. Shefer G, Van de Mark DP, Richardson JB, Yablonka-Reuveni Z. Satellite-cell pool size does matter: defining the myogenic potency of aging skeletal muscle. Dev Biol. 2006; 294: 50-66.

142. Carlson ME, Hsu M, Conboy IM. Imbalance between pSmad3 and Notch induces CDK inhibitors in old muscle stem cells. Nature. 2008; 454: 528-32.

143. Brack AS, Conboy MJ, Roy S, Lee M, Kuo CJ, Keller C, et al. Increased Wnt signaling during aging alters muscle stem cell fate and increases fibrosis. Science. 2007; 317: 807-10.

144. Brack AS, Rando TA. Intrinsic changes and extrinsic influences of myogenic stem cell function during aging. Stem Cell Rev. 2007; 3: 226-37. 
145. Yablonka-Reuveni Z, Seger R, Rivera AJ. Fibroblast growth factor promotes recruitment of skeletal muscle satellite cells in young and old rats. J Histochem Cytochem. 1999; 47: 23-42.

146. Neal A, Boldrin L, Morgan JE. The satellite cell in male and female, developing and adult mouse muscle: distinct stem cells for growth and regeneration. PLoS ONE. 2012; 7: e37950. doi: 10.1371/ journal.pone.0037950.

147. Price FD, von Maltzahn J, Bentzinger CF, Dumont NA, Yin H, Chang NC, et al. Inhibition of JAK-STAT signaling stimulates adult satellite cell function. Nat Med. 2014; 20: 1174-81.

148. Faulkner JA, Brooks SV, Zerba E. Muscle atrophy and weakness with aging: contraction-induced injury as an underlying mechanism. J Gerontol A Biol Sci Med Sci. 1995; 50 Spec No: 124-9.

149. Alnaqeeb MA, Goldspink G. Changes in fibre type, number and diameter in developing and ageing skeletal muscle. J Anat. 1987; 153: 31-45.

150. Marshall PA, Williams PE, Goldspink G. Accumulation of collagen and altered fiber-type ratios as indicators of abnormal muscle gene expression in the mdx dystrophic mouse. Muscle Nerve. 1989; 12: 528-37.

151. Aiken J, Bua E, Cao Z, Lopez M, Wanagat J, McKenzie D, et al. Mitochondrial DNA deletion mutations and sarcopenia. Ann NY Acad Sci. 2002; 959: 412-23.

152. Radak Z, Chung HY, Goto S. Systemic adaptation to oxidative challenge induced by regular exercise. Free Radic Biol Med. 2008; 44: 153-9.

153. Collins-Hooper H, Wooley TE, Dyson L, Patel A, Potter P, Baker RE, et al. Age-related changes in speed and mechanism of adult skeletal muscle stem cell migration. Stem Cells. 2012; 30: 1182-95.

154. Schultz E. Changes in the satellite cells of growing muscle following denervation. Anat Rec. 1978; 190: 299-311.

155. Rodrigues Ade C, Schmalbruch H. Satellite cells and myonuclei in long-term denervated rat muscles. Anat Rec. 1995; 243: 430-7.

156. Viguie CA, Lu DX, Huang SK, Rengen H, Carlson BM. Quantitative study of the effects of long-term denervation on the extensor digitorum longus muscle of the rat. Anat Rec. 1997; 248: 346-54.

157. Fahim MA, Robbins N. Ultrastructural studies of young and old mouse neuromuscular junctions. J Neurocytol. 1982; 11: 641-56.

158. Christov C, Chretien F, Abou-Khalil R, Bassez G, Vallet G, Authier FJ, et al. Muscle satellite cells and endothelial cells: close neighbors and privileged partners. Mol Biol Cell. 2007; 18: 1397-409.

159. Schmalbruch H, Hellhammer U. The number of nuclei in adult rat muscles with special reference to satellite cells. Anat Rec. 1977; 189: $169-75$

160. Prior BM, Lloyd PG, Yang HT, Terjung RL. Exercise-induced vascular remodeling. Exerc Sport Sci Rev. 2003; 31: 26-33.

161. Ryan NA, Zwetsloot KA, Westerkamp LM, Hickner RC, Pofahl WE, Gavin TP. Lower skeletal muscle capillarization and VEGF expression in aged vs. young men. J Appl Physiol. 2006; 100: 17885.

162. Brandes RP, Fleming I, Busse R. Endothelial aging. Cardiovasc Res. 2005; 66: 286-94.

163. Ashcroft GS, Mills SJ, Ashworth JJ. Ageing and wound healing. Biogerontology. 2002; 3: 337-45.

164. Doumit ME, Cook DR, Merkel RA. Testosterone up-regulates androgen receptors and decreases differentiation of porcine myogenic satellite cells in vitro. Endocrinology. 1996; 137: 138594.

165. Joubert Y, Tobin C. Testosterone treatment results in quiescent satellite cells being activated and recruited into cell cycle in rat levator ani muscle. Dev Biol. 1995; 169: 286-94.

166. Sinha-Hikim I, Cornford M, Gaytan H, Lee ML, Bhasin S. Effects of testosterone supplementation on skeletal muscle fiber hypertrophy and satellite cells in community-dwelling older men. J Clin Endocrinol Metab. 2006; 91: 3024-33.

167. Herbst KL, Bhasin S. Testosterone action on skeletal muscle. Curr Opin Clin Nutr Metab Care. 2004; 7: 271-7.

168. Van den Beld AW, de Jong FH, Grobbee DE, Pols HA, Lamberts SW. Measures of bioavailable serum testosterone and estradiol and their relationships with muscle strength, bone density, and body composition in elderly men. J Clin Endocrinol Metab. 2000; 85: 3276-82.

169. Goodpaster BH, Wolf D. Skeletal muscle lipid accumulation in obesity, insulin resistance, and type 2 diabetes. Pediatr Diabetes. 2004; 5: 219-26.

170. Visser M, Goodpaster BH, Kritchevsky SB, Newman AB, Nevitt M, Rubin SM, et al. Muscle mass, muscle strength, and muscle fat infiltration as predictors of incident mobility limitations in wellfunctioning older persons. J Gerontol A Biol Sci Med Sci. 2005; 60: 324-33.

171. Pahor M, Kritchevsky S. Research hypotheses on muscle wasting, aging, loss of function and disability. J Nutr Health Aging. 1998; 2: 97-100.

172. Delmonico MJ, Harris TB, Visser M, Park SW, Conroy MB, Velasquez-Mieyer P, et al. Longitudinal study of muscle strength, quality, and adipose tissue infiltration. Am J Clin Nutr. 2009; 90: 1579-85.

173. Emery AE. The muscular dystrophies. Lancet. 2002; 359: 687-95.

174. McNally EM, Pytel P. Muscle diseases: the muscular dystrophies. Annu Rev Pathol. 2007; 2: 87-109.

175. Wren TA, Bluml S, Tseng-Ong S, Gilsanz V. Three-point technique of fat quantification of muscle tissue as a marker of disease progression in Duchenne muscular dystrophy: preliminary study. AJR Am J Roentgenol. 2008; 190: W8-12.

176. Birbair A, Zhang T, Wang ZM, Messi ML, Enikopolov GN, Mintz $\mathrm{A}$, et al. Role of pericytes in skeletal muscle regeneration and fat accumulation. Stem Cells Dev. 2013; 22: 2298-314.

177. Power GA, Dalton BH, Rice CL. Human neuromuscular structure and function in old age: A brief review. J Sport Health Sci. 2013; 2: 21526.

178. Liu L, Rando TA. Manifestations and mechanisms of stem cell aging. J Cell Biol. 2011; 193: 257-66.

179. Bentzinger CF, Rudnicki MA. Rejuvenating aged muslce stem cells. Nat Med. 2014; 20: 234-5.

180. Tang AH, Rando TA. Induction of autophagy supports the bioenergetic demands of quiescent muscle stem cell activation. EMBO J. 2014; 33: 2782-97.

181. Diaz-Ruiz A, Gonzalez-Freire M, Ferrucci L, Bernier M, de Gabo R. SIRT1 synchs satellite cell metabolism with stem cell fate. Cell Stem Cell. 2015; 16: 103-4.

182. Ryall JG, Dell'Orso S, Derfoul A, Juan A, Zare H, Feng X, et al. The NAD(+)-dependent SIRT1 deacetylase translates a metabolic switch into regulatory epigenetics in skeletal muscle stem cells. Cell Stem Cell. 2015; 16: 171-83.

183. Tonkin J, Villarroya F, Puri PL, Vinciguerra M. SIRT1 signaling as potential modulator of skeletal muscle diseases. Curr Opin Pharmacol. 2012; 12: 372-6.

184. Cerletti M, Jang YC, Finley LW, Haigis MC, Wagers AJ. Short-term calorie restriction enhances skeletal muscle stem cell function. Cell Stem Cell. 2012; 10: 515-9.

185. Mercken EM, Mitchell SJ, Martin-Montalvo A, Minor RK, Almeida $\mathrm{M}$, Gomes AP, et al. SRT2104 extends survival of male mice on a standard diet and preserves bone and muscle mass. Aging Cell. 2014; 13: 787-96. 